\title{
THE CONCEPT OF THE HOLY SPIRIT IN EPHESIANS 1
}

\author{
Archie W.D. Hui
}

\section{Some Recent Studies on Ephesians}

Alongside the long-running debate on Ephesians' authenticity or pseudonymity, there has been a steady stream of studies on various themes of the epistle by scholars of both persuasions. These include J.C. Kirby's study of baptism and Pentecost, $\mathrm{H}$. Merklein's study of church office, A. Lindemann's (and, almost a decade later, H.E. Lona's) study of eschatology, C.C. Caragounis' study of mystery, T.G. Allen's study of the body of Christ, E. Penner's study of enthronement, K. Usami's study of church unity, and more recently C.E. Arnold's study of power and magic.

\section{J. Adai's Contribution}

To this list, we should add J. Adai's Der Heilige Geist als Gegenwart Gottes in den einzelnen Christen, in der Kirche und in der Welt: Studien zur Pneumatologie des Epheserbriefes (1985). This study of the Holy Spirit in Ephesians is significant because it differs from earlier works (such as those by N.Q. Hamilton, C.H. Pinnock, D. Hill, J.D.G. Dunn, and G.T. Montague) in that it treats Ephesians' pneumatology in its own right and not simply as a part of Pauline pneumatology and tradition, thus advancing scholarship a stage further.

Adai's perception is that Ephesians reflects a deuteroPauline pneumatology. Furthermore, not only is its pneumatology influenced by Paul and his tradition, but it also developed at times in the Lucan direction. These developments could be conveniently summarised under four major headings.

\section{The Spirit and Christ}

In contrast to Paul who closely links the Spirit with Christ, in Ephesians the Spirit is more independent of Christ as may be

${ }^{1}$ Archie W.D. Hui, The Concept of the Holy Spirit in Ephesians and its Relation to the Pneumatologies of Luke and Paul (Unpublished PhD Thesis, Aberdeen 1992). 
seen in the triadic references to God the Father, Christ Jesus the Lord, and the Holy Spirit (Eph. 1:3, 13, 2:18, 4:4-6).

\section{The Spirit and eschatology}

In contrast to Paul who understands the presence of the Spirit as the sign or mark of eschatological end-time, Ephesians (not unlike Acts) understands the coming of the Spirit as the beginning of a new era of salvation with little attention paid to the end or parousia (Eph. 1:13-14, 2:18, 22, 4:3-4, 30).

\section{The Spirit and the believer}

In contrast to Paul who emphasises the believer's participation in Christ, Ephesians emphasises the continuous process of the believer's renewal by the Spirit (Eph. 4:23-24). Paul's ethical dualism of flesh and Spirit has also been modified into a cosmic dualism of the two spirits (Eph. 2:2, 6:12).

\section{The Spirit and the church}

In contrast to Paul who perceives the local church as a charismatic community, Ephesians (not unlike Acts) perceives the universal church as a pneumatic institution with its various office-bearers (Eph. 2:20, 3:5, 4:11).

\section{The Questions Raised}

From this summary, it is obvious that Adai's thesis raises two important questions. First, what is the relationship between Lucan and Pauline pneumatologies? Second, what is the relationship of these to Ephesians' pneumatology? Regrettably, Adai's thesis does not answer these questions satisfactorily as it suffers from two methodological weaknesses which cast considerable doubts on the accuracy of his findings.

1. It presupposes the deutero-Pauline and, despite some reservations, Lucan authorship of Ephesians. Not surprisingly, the dissimilarities between Ephesians and Paul, as well as the similarities between Ephesians and Luke-Acts, are often overstated.

2. While the thesis compares Ephesians with Luke-Acts and with Paul respectively, it does not compare Luke-Acts with Paul which would give a proper background and context to assess Ephesians' relationship to both. Adai, in effect, has overlooked the modern debate (since O. Pfleiderer and $\mathrm{H}$. Gunkel) on the relationship of Lucan and Pauline pneumatologies. Of late, this debate has been fuelled by the 
significant contributions of J.D.G. Dunn and M.M.B. Turner and, most recently, by R.P. Menzies' work on the development of early Christian pneumatology.

\section{The Proposed Solution}

In view of the above, it is necessary to look afresh at the concept of the Holy Spirit in Ephesians and its relationship to the pneumatologies of Luke and Paul. This we do by examining in consecutive chapters the Spirit's relationship to Christ, eschatology, the believer, and the Christian church. In distinct contrast to Adai, however, we begin each of our chapters with an investigation of the various scholarly propositions on Lucan and Pauline pneumatologies. Only after such an investigation do we turn to the pneumatology of Ephesians to see how it relates to those of Luke and Paul.

In our examination of the New Testament materials, we find that while there are some similarities between the pneumatologies of Ephesians and Luke-Acts, they are mostly of a general nature belonging to the common core of early Christian tradition. For the more specific similarities, it is significant that these tend to be coincidental rather than conceptually related. For example, both Ephesians 5:18 and Acts 2:1-21 contrast the fullness of the Spirit with drunkenness. But while the former contrast is primarily sapiential and ethical, having to do with the life-style of the believers: the latter is phenomenal and verbal, having to do with a speech event.

Furthermore, we find that the more telling similarities, both in language and in concept, are between Ephesians and Paul. These could perhaps be listed under seven headings.

\section{The Christological aspect}

Both Ephesians and Paul see the corporate Christ as the sphere of God's gift of the Spirit. Both use the imageries of building and temple to highlight Christ's foundational role in the formation of the church and the Spirit's indwelling presence in that church.

\section{The eschatological aspect}

Both see the Spirit as God's eschatological seal, first instalment, spiritual blessing, and divine presence in his new temple. Both understand the gift of the Spirit as the fulfilment of Ezekiel's, 
rather than Joel's, promise. Both link the Spirit with the future, as well as the present, aspect of eschatology.

\section{The prophetic aspect}

Both associate the revelatory work of the Spirit with the salvific mystery of God which has to do with the believer's future inheritance and glory. Both emphasise charismatic diffusion, rather than charismatic injection, of wisdom and revelation.

\section{The soteriological aspect}

Both see the Spirit as God's seal of ownership of the believer, and the first instalment of the believer's eschatological inheritance. Both link the Spirit explicitly with the believer's sonship to God.

\section{The ethical aspect}

Both link the Spirit with mutual edification in the context of corporate worship, with charismatic wisdom in daily living, and with the transforming power of God conforming the believer to the image of Christ. Both contrast the Spirit with the flesh in an ethical dualism.

\section{The ecclesiological aspect}

Both see the Spirit as the presence of God in his one temple, and the gift of Christ to his one body. Both stress the common endowment of the Spirit on all the believers. Both emphasise the edifying and unifying effect of the Spirit in the church.

\section{The missiological aspect}

While Luke tends to highlight the role of the Spirit in the evangelistic mission of the church, both Ephesians and Paul tend to highlight the role of the Spirit in the ecclesiological interaction of the believers for mutual edification and growth.

Thus, we cannot agree with Adai's findings in Section II above that when Ephesians is compared to Paul, the Spirit is more independent of Christ, more rooted in salvation history, more cosmic in its dualism, and more institutionalised in the Christian church. The conclusion of our thesis is that the pneumatology of Ephesians is not Lucan; it is not deuteroPauline; it is simply Pauline. 